\title{
Work-related injuries in textile industry workers in Turkey
}

\author{
Türkiyede tekstil sektörü çalışanlarında iş kazalarına bağlı yaralanmalar
}

\author{
Mustafa SERİNKEN, ${ }^{1}$ İbrahim TÜRKÇÜER, ${ }^{1}$ Bekir DAĞLI, ${ }^{1}$ \\ Özgür KARCIOĞLU, ${ }^{2}$ Mehmet ZENCİR, ${ }^{3}$ Emrah UYANIK ${ }^{1}$
}

\section{BACKGROUND}

This study was conducted as a survey including work-related injuries (WRI) of workers in the textile and clothing industry admitted to the emergency department (ED).

\section{METHODS}

This prospective study included patients with WRI reportedly occurring in the textile and clothing industry over a two-year period. The study sample comprised only the casualties occurring at the workplace and while working de facto.

\section{RESULTS}

A total of 374 patients were eligible for the study. More than three-fourths of the study sample were females $(76.2 \%$, $\mathrm{n}=285$ ). A significant proportion of the patients were between 14 and 24 years of age $(44.7 \%, n=167)$. Approximately twothirds reported that this was their first admission to a hospital related to WRI $(65.8 \%, \mathrm{n}=246)$. WRIs occurred most frequently between 07:00-09:00 (27.3\%) and 23:00-01:00 (17.9\%). "Carelessness" and "rushing" were the most commonly reported causes of WRIs from the patients' perspective (40.6\% and $21.4 \%$, respectively). Three-fourths of the patients reported that they were using protective equipment (74.3\%, $\mathrm{n}=278)$. With respect to injury types, laceration/ puncture/ amputation/avulsion injuries accounted for $55.6 \%$ $(n=208)$ of the sample. Trauma to the upper extremities was the main type of injury in $75.1 \%(n=281)$ of the cases.

\section{CONCLUSION}

Broad population-based studies are needed to define the situation as a whole in WRIs in the textile and clothing industry in the country. Strict measures should be undertaken and revised accordingly to prevent WRIs in these growing sectors.

Key Words: Emergency department; occupational injuries; textile industry; work-related injuries.

\section{$\boldsymbol{A M A C}$}

$\mathrm{Bu}$ çalışma, acil servise başvuran tekstil ve giyim sektörü çalışanlarında işle ilgili yaralanmaları araştırmak için yapild1.

\section{GEREÇ VE YÖNTEM}

Prospektif tasarlanan çalışmaya iki yıllık araştırma süresince tekstil ve dokuma endüstrisinde çalışanların iş kazaları ile ilişkili başvurular alındı. Çalışma örnekleminde sadece iş yerinde ve fiilen çalışma sırasında olan yaralanmalar analiz edildi.

\section{BULGULAR}

Toplam 374 hasta çalışma kriterlerine uygun bulundu. Olguların büyük bölümünü kadınlar $(\% 76,2, n=285)$, yaş dilimleri içinde ise 14-24 yaş arasındakiler oluşturdu (\%44,7, $\mathrm{n}=167)$. Olguların yaklaşık üçte ikisi iş kazasına bağ11 olarak ilk kez hastaneye başvurduğunu bildirdi $(\% 65,8$, $\mathrm{n}=246)$. İş kazaları en sık 07:00 ile $09.00(\% 27,3)$ ve 23:00 ile 01:00 $(\% 17,9)$ saatleri arasında oluştu. Hastalar kazaların nedenini en sik olarak dikkatsizlik ve acelecilik olarak bildirdi (sırasiyla, \%40,6 ve \%21,4). Hastaların yaklaşık dörtte üçü olay sırasında koruyucu malzeme kullandığını bildirdi $(\% 74,3, n=278)$. Yaralanma tiplerine bakıldığında, kesi/batma/amputasyon/ avulsiyon yaralanmaları $\% 55,6(n=208)$ oranındaydı. En sik olarak üst ekstremite yaralanması $(\% 75,1 \mathrm{n}=281)$ görüldü.

\section{SONUÇ}

Ülkemizde tekstil ve dokuma endüstrisinde çalışanların iş kazalarını bir bütün olarak tanımlamak için geniş, toplum tabanlı araştırmalara gereksinim vardır. Hızla gelişen bu sektörde iş kazalarının azaltılması için düzenlemeler yapılmalıdir.

Anahtar Sözcükler: Acil servis; mesleki yaralanmalar; tekstil sanayi; iş kazaları.
Departments of ${ }^{1}$ Emergency Medicine, ${ }^{3}$ Public Health, Pamukkale University, Faculty of Medicine, Denizli; ${ }^{2}$ Department of Emergency Medicine, Acibadem University, Faculty of Medicine, Istanbul, Turkey.
Pamukkale Üniversitesi Tıp Fakültesi, ${ }^{1}$ Acil Tıp Anabilim Dalı, ${ }^{3}$ Halk Sağlığı Anabilim Dalı, Denizli; Acıbadem Üniversitesi Tıp Fakültesi, Acil Tıp Anabilim Dalı, Denizli. 
The textile and clothing industry grows rapidly, while witnessing a harsh rivalry throughout the world. Turkey ranked as the 7th largest exporter in textile and 4th in haute couture in 2007. Those two items comprise up to one-third of the exported sum of the country. ${ }^{[1]}$ In this context, Denizli, in western Turkey, is one of the leading industrialized cities carrying a majority of the industry load. ${ }^{[2]}$ The city has a population of approximately 900,000 . There are about 30,000 textile ateliers, which weave a total of 1000 tons of rope per day. Around 14,600 employees work in textile factories, which are mostly situated in organized industry zones. The total number of employees in the textile industry is 35,000 , including those in 550 factories. The workers are generally assigned into three shifts $(07: 00-15: 00,15: 00-23: 00,23: 00-07: 00)$ in these factories, while some small enterprises employ two 12-hour shifts, mostly 7 days a week. More than $3 \%(2,500 / 73,923)$ of countrywide occupational accidents in 2005 consisted of injuries registered in databases in this single city. Another interesting fact is that the male-to-female ratio in occupational accidents is much lower in Denizli when compared to the countrybased figures ( 7.7 vs. 21.1) due to predominance of the textile sector, in which the majority of the workforce is comprised of women in the city. Metal-machinery and mining are the other common areas of employment in the region. ${ }^{[2,3]}$

More than 2500 admissions due to occupational injuries are recorded in the health facilities annually in Denizli. ${ }^{[4]}$ Severe injuries and multiple casualties generally tend to be transported with state-run ambulance services (112), while other casualties are handled via the facility's own resources. Around one-third of the patients exposed to work-related injuries (WRI) are referred to the University hospital, which has the most advanced technology in the city. The facility has 24hour coverage regarding replantation, microsurgery and other advanced interventions for occupational injuries, in contrast to the other hospitals. Therefore, the patients are commonly transferred from other hospitals to the University hospital.

The Social Security Institution (SSK) is the largest or main state-run institution established to manage the social security issues of the Turkish workers. Unregistered workers constitute up to $46.2 \%$ of the entire working population according to Turkish statistics compiled in 2007, despite sanctions pursued by the state. ${ }^{[5]}$ This phenomenon, namely, precarious workforce, is widespread in the textile sector in Turkey, as seen in many developing countries. This is reflected in agreements with the employers, income, and insurance status, etc. Coupled with the high circulation rate of the labor force, the sector can be seen as highly staffed by inexperienced young workers.
In brief, WRI is a commonly encountered public health problem in the textile sector in the region. Although rarely fatal, these injuries are estimated to cause serious illnesses in association with substantial workforce losses and financial burden.

This study was conducted as a survey recruiting workers in the textile and clothing industry exposed to WRI and consequently admitted into the University-based emergency department (ED). The objective of the study was to analyze epidemiological data and mechanisms and characteristics of injury in the sector.

\section{MATERIALS AND METHODS}

This prospective study included patients with WRI reportedly occurring in the textile and clothing industry over a two-year period (2006-2008). Institutional Review Board approval was obtained before commencement of the study. The study sample comprised only the casualties occurring in the workplace and while working de facto. Excluded were the events occurring while commuting to and from work. The data sheets comprised sociodemographic and injury-related information accumulated in a 15-item questionnaire. A special data recording system was developed for the prospective study. The data were abstracted via face-to-face contact in the ED. Causes of occupational injuries as reported by the victims were assigned to one of two groups as 'worker-related causes' and 'workplace-related causes'.

An isolated room in the ED was used for this purpose in order to prevent bias, and the patients were not accompanied by any person other than the medical personnel in charge of due medical care. The patients were also assured that the information obtained by the survey was to be used for research purposes only and that no feedback was to be given to employers or related persons.

Patients who did not give consent for the study, fatal accidents and patients younger than 14 years of age were excluded from the analysis.

\section{Statistical Analysis}

All data obtained in the study were recorded in and analyzed using the Statistical Package for the Social Sciences for Windows, version 11. Numerical variables were given as mean and standard deviation (SD), while categorical variables were given as frequencies (n) and percentages.

\section{RESULTS}

\section{Demographic Data}

A total of 1335 patients were admitted to the ED due to occupational injuries within the two-year study period. Following the metal industry and machinery 
Table 1. Sociodemographic characteristics of WRI among the 374 study subjects

\begin{tabular}{|c|c|c|}
\hline Sociodemographic variables & $\mathrm{n}$ & $\%$ \\
\hline \multicolumn{3}{|l|}{ Sex } \\
\hline Male & 89 & 23.8 \\
\hline Female & 285 & 76.2 \\
\hline \multicolumn{3}{|l|}{ Age } \\
\hline $14-24$ & 167 & 44.7 \\
\hline $25-34$ & 147 & 39.3 \\
\hline$>34$ & 60 & 16.0 \\
\hline \multicolumn{3}{|l|}{ Social security status } \\
\hline Social Security Institution (SSK) & 308 & 82.3 \\
\hline None & 40 & 10.7 \\
\hline $\begin{array}{l}\text { Other (Other state-run institution } \\
\text { or private insurance) }\end{array}$ & 26 & 6.8 \\
\hline \multicolumn{3}{|l|}{ Level of education } \\
\hline Illiterate & 14 & 3.8 \\
\hline Elementary school & 87 & 23.2 \\
\hline Secondary school-college & 234 & 62.6 \\
\hline University-high school & 39 & 10.4 \\
\hline \multicolumn{3}{|l|}{ Years worked in the sector } \\
\hline $1-3$ yrs & 240 & 64.2 \\
\hline $3-6$ yrs & 49 & 13.1 \\
\hline$>6$ yrs & 85 & 22.7 \\
\hline \multicolumn{3}{|l|}{$\mathrm{N}$ of previous WRIs reported } \\
\hline 0 & 246 & 65,8 \\
\hline 1 & 99 & 26,5 \\
\hline$\geq 2$ & 29 & 7,7 \\
\hline \multicolumn{3}{|l|}{ Day of injury } \\
\hline Monday & 84 & 22.5 \\
\hline Tuesday & 60 & 16.0 \\
\hline Wednesday & 39 & 10.4 \\
\hline Thursday & 40 & 10.7 \\
\hline Friday & 34 & 9.1 \\
\hline Saturday & 66 & 17.6 \\
\hline Sunday & 51 & 13.6 \\
\hline \multicolumn{3}{|l|}{ Mode of disposition } \\
\hline Discharge & 282 & 75.4 \\
\hline Admission & 92 & 24.6 \\
\hline
\end{tabular}

$(30.1 \%)$, textile was the second largest field with a high percentage of WRIs (384 cases, 28.7\%). Eight cases $(2.1 \%)$ out of 384 refused to participate in the study, while $2(0.5 \%)$ fatal occupational injuries were excluded from the analysis. The remaining 374 eligible patients composed the study group.

Three-fourths of the study sample were females $(76.2 \%, \mathrm{n}=285)$. The mean age of the patients was $26.6 \pm 7.6$ years (range: $14-59)$ (31.3 \pm 7.9 for males; $25.2 \pm 6.2$ for females), with the largest percentage aged $14-24$ years $(44.7 \%, n=167)$.

Although a majority of the patients had been registered in social security institutions, 40 cases $(10.7 \%)$ had no insurance, which is legally banned in Turkey.
The average number of years worked in the sector was $4.5 \pm 3.6$ years (range: $1-32$ ). The majority had worked between 1 and 3 years $(64.2 \%, n=240)$. When the patients were asked if they had suffered from such injury before, approximately two-thirds reported that this was their first admission to a hospital related to WRI $(65.8 \%, \mathrm{n}=246)$ (Table 1$)$.

WRIs occurred most frequently between 07:0009:00 (27.3\%) and 23:00-01:00 (17.9\%) (Fig. 1). Monday was the most common day of injuries $(22.5 \%$, $n=84)$. Nearly one- third of all WRIs were noted to have occurred on the weekend (31.3\%) (Table 1).

Emergency care and management was sufficient for $75.4 \%(n=282)$ of the cases, who were discharged from the ED, while $24.6 \%$ ( $n=92)$ were admitted to the hospital. The mean length of stay in the hospital was $5.7 \pm 2.9$ days.

\section{Causes of Injuries (Self-Reported)}

Patients were asked to clarify the source of their injury. The responses were assigned into three groups, as worker-related causes, workplace-related causes, or both. More than half of the patients $(57.8 \%, n=216)$ reported that their injury resulted from solely workerrelated causes, while $13.9 \%(\mathrm{n}=52)$ cited workplacerelated causes as the culprit. The rest of the sample considered that both factors were responsible $(28.3 \%$, $\mathrm{n}=106$ ).

"Carelessness" and "rushing" were the most commonly reported causes of WRIs from the patients' perspective (40.6\% and $21.4 \%$, respectively). Improper physical conditions in the workplace (floor, noise, heat, chaos/untidiness) was the third most commonly reported cause (Table 2). Three-fourths of the patients reported that they were using protective equipment (such as gloves, goggles and gown, etc.) (74.3\%, $\mathrm{n}=278$ ) at the moment of the event. On the other hand, $12.3 \%(\mathrm{n}=46)$ of the patients reported that this equipment was not available in sufficient quantities or was unavailable in their workplace.

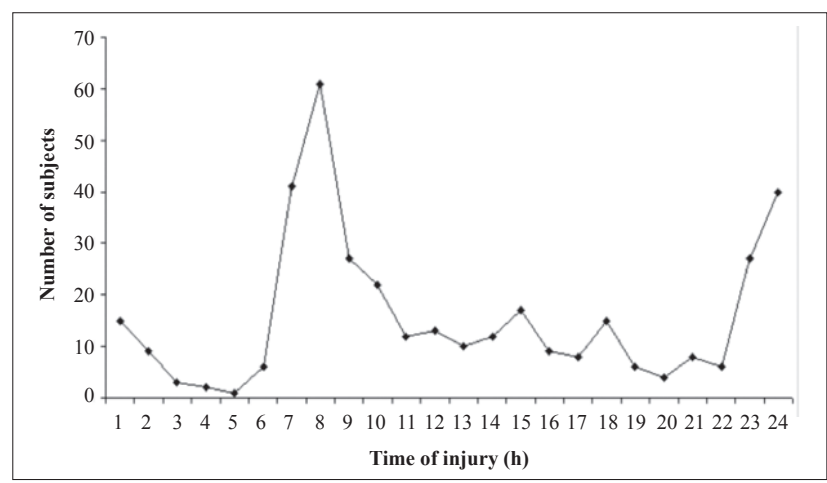

Fig. 1. The time of the injury for work-related injuries among the 374 study subjects. 
Table 2. Causes of occupational injuries as reported by the victims

\begin{tabular}{lcc}
\hline Causes of Injuries & $\mathrm{n}^{*}$ & $\%$ \\
\hline Worker-related causes (n=390) & & \\
Carelessness & 201 & 40.6 \\
Rushing & 106 & 21.4 \\
Sleepiness & 37 & 7.5 \\
Inexperience & 21 & 4.3 \\
Not duly trained & 11 & 2.2 \\
Not using/lack of protective measures & 10 & 2.0 \\
Other & 4 & 0.8 \\
Workplace-related causes (n=105) & & \\
Improper physical conditions in the workplace & & \\
(floor, noise, heat, chaos/untidiness) & 53 & 10.7 \\
Lack of protective measures & & \\
(unavailability of gloves, goggles, gown, etc.) & 45 & 9.1 \\
Other & 7 & 1.4 \\
Total & 495 & 100 \\
\hline
\end{tabular}

* Some patients reported more than one cause for their injuries.

\section{Physical Characteristics of Injuries}

Trapped hands in the machines $(46.5 \%, \mathrm{n}=174)$, misuse or improper use of the machines and tools $(13.1 \%, \mathrm{n}=49)$ and falls from height $(8.3 \%, \mathrm{n}=31)$ were the most common mechanisms of injury. Table 3 depicts the distribution of occupational injuries according to localization. With respect to injury types, laceration/puncture/amputation/avulsion injuries accounted for $55.6 \%(n=208)$ of the sample (Table 3$)$. Trauma to the upper extremities was present in $75.1 \%$ $(n=281)$ of the cases. Isolated finger injuries accounted for $65.8 \%(n=185)$ of upper extremity injuries (Table $4)$. The majority of the hand injuries involved the right hand $(74.0 \%, \mathrm{n}=137)$, and the index finger was the most commonly injured $(58.9 \%, n=109)$, followed by the thumb $(25.4 \%, \mathrm{n}=47)$ and third finger $(11.4 \%$, $\mathrm{n}=21$ ).

\section{DISCUSSION}

This study was conducted as a survey to investigate characteristics of WRI among workers in the textile and clothing industry admitted into the ED. These untoward events are shown to afflict more commonly the poorly educated, young female workers in the sector. The workers most commonly reported causes of WRIs as "carelessness" and "rushing" (40.6\% and $21.4 \%$, respectively).

Trapped hands in the machines was the mechanism of injury in nearly half of the victims in the present study. As for the localization of the injuries, threefourths of the patients suffered from trauma to the upper extremities, while laceration/puncture/amputation/ avulsion injuries were reported as the most common
Table 3. Physical characteristics of occupational injuries

\begin{tabular}{lcc}
\hline Location of the injury & $\mathrm{n}$ & $\%$ \\
\hline Head & 29 & 7.8 \\
Neck & 3 & 0.8 \\
Trunk & 11 & 2.9 \\
Upper limb & 281 & 75.1 \\
Lower limb & 36 & 9.6 \\
Multiple locations & 9 & 2.4 \\
General injuries & 5 & 1.3 \\
Total & 374 & 100.0 \\
Type of injury & & \\
Laceration/puncture/amputation/avulsion & 208 & 55.6 \\
Contusion/abrasion/hematoma/crush & 71 & 19.0 \\
Fracture/dislocation & 59 & 15.8 \\
Sprain/strain & 28 & 7.5 \\
Inhalation & 5 & 1.3 \\
Burn & 3 & 0.8 \\
Total & 374 & 100.0 \\
\hline
\end{tabular}

Table 4. Anatomical classification of the upper extremity injuries

\begin{tabular}{lcc}
\hline Location of the injury & $\mathrm{n}$ & $\%$ \\
\hline Shoulder & 8 & 2.9 \\
Arm and elbow & 15 & 5.3 \\
Forearm and wrist & 20 & 7.1 \\
Hand & 41 & 14.6 \\
Finger(s) & 185 & 65.8 \\
More than one body part listed above & 12 & 4.3 \\
Total & 281 & 100 \\
\hline
\end{tabular}

injury types, comprising more than half of the sample. Two-thirds of the upper extremity injuries were isolated finger injuries, and the index finger was the most commonly injured, while the right hand dominated over the left. The first day of the week and the first hours of the working shifts witnessed the peak rates of injuries.

Although the textile sector is one of the main industries for the country, scarce data are available on WRIs in the workplace. The Social Security Institution (SSK) reported that around 380,000 WRIs occurred in Turkey between 2001 and 2005, with only $4.6 \%$ being women. Of note, these data mostly reflect the injuries serious enough to be referred to a health facility and also those recorded by a social security institution. Thus, one can postulate that the real numbers are far more than these formal data. In 2005, around one-tenth of all WRIs in Turkey consisted of those reported in the textile sector. ${ }^{[5,6]}$

Data elicited from countries with a developed tex- 
tile industry demonstrate that female workers dominate the workforce. ${ }^{[7-9]}$ Formal reports cite that twofifths of women (1337 out of 3334) suffering from WRI in 2005 had been employed in the textile industry. ${ }^{[6]}$ The mean age of female workers involved in WRIs in Turkey was 29, whereas the corresponding figure in the present study was 25.2. Nearly half of the patients were between 14 and 24 years of age $(44.7 \%)$. In China -the champion of haute-couture exportersnearly half of all workers were women between 20 and 24 years of age. ${ }^{[10]}$

Although legally banned in Turkey, around onetenth of the patients with WRI in this study sample had no insurance. Another interesting point in the present study is that WRI most commonly occurred among inexperienced workers who were new on the job. Workers who had been working in the sector between 1 and 3 years constituted up to two-thirds of the sample. National statistics reported that workers with less than one year's experience account for $18.7 \%$ of those with WRI, while $44.3 \%$ had been working less than two years. ${ }^{[5]}$ These findings are similar to the reports published by Perry et al. ${ }^{[8]}$

The precarious workforce is extensively exploited in the textile sector in Turkey. It can be seen as unregistered employment, temporary employment and other forms. All these deceptive acts result in decreased costs of labor and extremely rapid turnover of the workforce. The end products of all these are precarious, inexperienced workers who work for longer than recommended, i.e., factors paving the way to WRIs.

Precarious employment is a major issue in the context of the World Health Organization (WHO) Commission for Social Determinants of Health. The EMCONET Study Group concluded that precarious labor appears to be an independent risk factor for inequalities in health services. Researches pointed out that this enhances rates of WRI and due mortality. ${ }^{[1]}$ Many studies showed that precarious employment is also a major risk factor in non-lethal WRIs. ${ }^{[12-14]}$ Benavides et al. ${ }^{[15]}$ investigated the mechanisms of WRIs in uninsured and temporary workers. They emphasized that short work experience, deficient knowledge of dangers in the workplace and short maintenance periods on any given job are associated with WRIs.

It is known that most WRIs are recorded in the starting hours in ateliers, both in the morning and evening [07:00-09:00 (27.3\%), 23:00-01:00 (15.8\%)]. Statistical reports cite that $18.5 \%$ of all occupational injuries in Turkey in 2005 occurred within the first working hour, while $33.7 \%$ were noted in the first two hours. Most WRIs in Turkey occurred between 08:0010:00 and 10:00-12:00 (19.6\% and 18.7\%, respectively). ${ }^{[5,6]}$ Justis et al. ${ }^{[16]}$ investigated occupational hand injuries and pointed out that $24 \%$ of work-related hand injuries occurred within the first working hour. On the same issue, Lombardi et al. ${ }^{[17]}$ reported that the highest frequency of injury was observed from 08:00-12:00 (54.6\%), with a peak from 10:00-11:00 a.m. (14.9\%). The median time into the work shift for injury was 3.5 hours.

Sanati et al. ${ }^{[18]}$ conducted a study with the workers in synthetic fiber factories and reported that almost half of the WRIs (46\%) involved the hand and the most common mechanism was falls from height. This study demonstrates that falls are a serious safety concern in the workplace. On the other hand, falls were the third most common mechanism of injury in the present study, following trapped hands and misuse of tools and machines. Another Turkish study on workrelated hand injuries also put forth that trapped hands in machines was the most common mechanism of injury $(59.7 \%){ }^{[19]}$

Ind et al. ${ }^{[20]}$ emphasized the importance of needlestick-type injuries among workers in the clothing industry. Laceration and puncture-type injuries comprised a substantial part of WRIs referred to the ED in this study. Perry et al. ${ }^{[8]}$ indicated that cutting/piercing instruments were the major culprits in WRI, and a major part of WRI diagnoses consisted of open wounds involving the upper limb (29.0\%).

The index finger was the most commonly injured $(58.9 \%, \mathrm{n}=109)$, followed by the thumb $(25.4 \%$, $\mathrm{n}=47)$ and third finger $(11.4 \%, \mathrm{n}=21)$ in the present study. Previous studies indicated the most commonly involved digit as the middle finger, followed by the fourth and index fingers, respectively, regardless of the sector. ${ }^{[4,19]}$ This difference between findings may result from the tendency to use the index finger in textile machines, i.e., while feeding the machine with fabric.

The workers tended to blame themselves or selfrelated conditions instead of workplace-related circumstances as the cause of the WRIs. The causes most commonly reported were "carelessness" and "rushing" (40.6\% and $21.4 \%$, respectively). A number of other studies including all sectors have also mentioned "carelessness" as the most commonly blamed. ${ }^{[4,19]}$ These findings may have resulted from the worker's tendency to protect their own employer, indirectly defending themselves against unemployment and poverty. Recurrent questioning on the cause(s) of the accident may render findings to be extrapolated.

Three prominent risk factors for work-related hand injuries have been reported as lack of proper utilization of protective measures (gloves, etc.), insufficient work experience and worker-related factors (sleepiness, carelessness, etc.). ${ }^{\left[{ }^{[1]}\right.}$ Hertz et al. ${ }^{[22]}$ put forth that age under 25 is another risk factor. They also stressed that 
use of defective equipment at the moment of the injury and assignment of a non-typical task to the workers contribute to the occurrence of WRIs. Chow et al. ${ }^{[23]}$ described seven significant transient risk factors for acute hand injuries: using malfunctioning equipment/ materials, using a different work method, performing an unusual work task, working overtime, feeling ill, being distracted, and rushing.

The Turkish Statistical Institute declared that a 2.3\% annual growth rate was recorded in the textile sector and $1.8 \%$ in the clothing sector in 2007. ${ }^{[5]}$ This also indicates the need to augment the protective measures in these ever-growing fields in the country against WRIs. National policies are to be developed to curb further increases in precarious labor in terms of both employment and working conditions. Widespread application and improvization of workers' health and workplace safety will also have an appreciable role in diminishing WRIs. In this context, efforts are to be aimed at determination of the causes of WRI and identification of measures to eliminate these causes, while promoting safe behavioral patterns through robust training on the issue. These should be combined with improvement in workplace conditions and repeated inspections and sanctions pursued by the state. Finally, broad, population-based studies are to be conducted to highlight the risk factors for WRI in Turkey.

\section{REFERENCES}

1. World Trade Organization web site. International Trade Statistics 2004. available from http://www.wto.org/english/ res_e/statis_e/its2004_e/its04 bysector_e.htm. (Accessed 20 September 2010 ).

2. Serinken M, Karcioglu O, Zencir M, Turkcuer I. Direct medical costs and working days lost due to non-fatal occupational injuries in Denizli, Turkey. J Occup Health 2008;50:70-4.

3. Denizli Textile Exporters' Association web site. About Denizli - Economy. Available from http://www.detkib.org.tr/english/abautden.htm. (Accessed 20 September 2010).

4. Serinken M, Karcioglu O, Sener S. Occupational hand injuries treated at a tertiary care facility in western Turkey. Ind Health 2008;46:239-46.

5. Social Security Statistics, Turkish Statistical Institute (TURKSTAT) (online). Available from http://www.turkstat. gov.tr/VeriBilgi.do. (Accessed 20 September 2010).

6. Social Insurance Institution Yearly Statistical Report, 2005. Türkiye Sosyal Sigortalar Kurumu (SSK) Web Site. Available from: http://www.ssk.gov.tr. (Accessed 20 September 2010).

7. Checkoway H, Ray RM, Lundin JI, Astrakianakis G, Seixas NS, Camp JE, et al. Lung cancer and occupational exposures other than cotton dust and endotoxin among women textile workers in Shanghai, China. Occup Environ Med 2011;68:425-9.

8. Perry MJ, Sun BX, Zhang HX, Wang X, Christiani D. Emergency department surveillance of occupational injuries in Shanghai's Putuo District, People's Republic of China. Ann Epidemiol 2005; 15:351-7.

9. Cakir E, Uyan ZS, Varol N, Ay P, Ozen A, Karadag B, Effect of occupation and smoking on respiratory symptoms in working children. Am J Ind Med 2009;52:471-8.

10. Li W, Ray RM, Gao DL, Fitzgibbons ED, Seixas NS, Camp $\mathrm{JE}$, et al. Occupational risk factors for pancreatic cancer among female textile workers in Shanghai, China. Occup Environ Med 2006;63:788-93.

11. Benach J, Muntaner C, Solar O, Santana V, Quinlan M. Introduction to the WHO Commission on Social Determinants of Health Employment Conditions Network (EMCONET) study, with a glossary on employment relations. Int J Health Serv 2010;40:195-207.

12. Santana VS, Loomis D. Informal jobs and non-fatal occupational injuries. Ann Occup Hyg 2004;48:147-57.

13. Benavides FG, Delclos J, Benach J, Serra C. Occupational injury, a public health priority. [Article in Spanish] Rev Esp Salud Publica 2006;80:553-65.

14. Saha A, Kulkarni PK, Chaudhuri R, Saiyed H. Occupational injuries: is job security a factor? Indian J Med Sci 2005;59:375-81.

15. Benavides FG, Benach J, Muntaner C, Delclos GL, Catot N, Amable M. Associations between temporary employment and occupational injury: what are the mechanisms? Occup Environ Med 2006;63:416-21.

16. Justis EJ, Moore SV, LaVelle DG. Woodworking injuries: an epidemiologic survey of injuries sustained using woodworking machinery and hand tools. J Hand Surg Am 1987;12:8905.

17. Lombardi DA, Sorock GS, Hauser R, Nasca PC, Eisen EA, Herrick RF, Temporal factors and the prevalence of transient exposures at the time of an occupational traumatic hand injury. J Occup Environ Med 2003;45:832-40.

18. Sanati KA, Yadegarfar G, Naghavi SH, Sadr AH, Gholami M, Hadipour M, et al. Occupational injuries in a synthetic fibre factory in Iran. Occup Med (Lond) 2009;59:62-5.

19. Unlü RE, Abacı Ünlü E, Orbay H, Sensöz O, Ortak T. Crush injuries of the hand. [Article in Turkish] Ulus Travma Derg 2005; 11:324-8.

20. Ind JE, Jeffries DJ. Needlestick injury in clothing industry workers and the risks of blood-borne infection. Occup Med (Lond) 1999;49:47-9.

21.Lombardi DA, Sorock GS, Holander L, Mittleman MA. A case-crossover study of transient risk factors for occupational hand trauma by gender. J Occup Environ Hyg 2007;4:790-7.

22. Hertz RP, Emmett EA. Risk factors for occupational hand injury. J Occup Med 1986;28:36-41.

23. Chow CY, Lee H, Lau J, Yu IT. Transient risk factors for acute traumatic hand injuries: a case-crossover study in Hong Kong. Occup Environ Med 2007;64:47-52. 